\title{
$72 \mathrm{~Hz}$ 大冷量空间脉冲管制冷机
}

\author{
王乃亮 ${ }^{1,2}$, 赵密广 $1^{*}$, 陈厚䂞 ${ }^{1}$, 梁惊涛 ${ }^{1}$ \\ 1. 中国科学院理化技术研究所空间功热转换技术重点实验室 北京 100190 ; \\ 2. 中国科学院大学 北京 100049 \\ * 联系人, E-mail: mgzhao@ mail.ipc.ac.cn
}

2018-01-25 收稿, 2018-04-04 修回, 2018-04-19 接受, 2018-12-05 网络版发表

国家自然科学基金(51776213)、国家重点基础研究发展计划(613322)和国家重点研发计划(2016YFB0500500)资助

\begin{abstract}
摘要空间应用对低温制冷机的体积与重量有着较高的限制, 然而目前 $10 \mathrm{~W}$ 级以上的空间制冷机重量均较大, 不能满足空间应用的需求，因此轻量化脉冲管制冷机的研制工作迫在眉睫. 相关研究表明，提高制冷机的运行频 率, 是实现制冷机轻量化的一种有效途径. 为了提高制冷机的运行频率, 本文首先从理论上分析了蓄冷器长度、蓄 冷器填料、充气压力等因素对制冷机运行频率及制冷效率的影响规律. 随后加工了 $35 \mathrm{~mm} 45 \mathrm{~mm}$ 长度的脉冲管 制冷机的冷指, 并通过实验对制冷机的蓄冷器填料、充气压力等进行了优化. 最终成功研制了一台 $72 \mathrm{~Hz}$ 同轴型大 冷量脉冲管制冷机, 其在 $250 \mathrm{~W}$ 输入电功下, 具有 $12 \mathrm{~W} @ 80 \mathrm{~K}$ 的冷量, 相对电功卡诺效率可达 $13.2 \%$, 整机效率 较高.
\end{abstract}

关键词 $12 \mathrm{~W} @ 80 \mathrm{~K}$, 同轴，脉冲管, $72 \mathrm{~Hz}$

目前，搭载在航天卫星上的红外探测器件，均需 要依靠低温制冷机将其冷却到液氮温区附近, 以提 高探测器件的灵敏度与探测范围. 脉冲管制冷机作 为新一代空间低温制冷机，具有结构简单、运行寿命 长、冷指振动小、抗电磁干扰、可靠性高等优势, 尤 其在红外探测领域具有广阔的应用前景. 近年, 航天 红外探测器件逐渐朝着大面阵、长线列、多光谱的方 面发展, 红外探测器件需求的冷量逐年攀升. 为了应 对这种需求, 低温制冷机也逐渐朝着大冷量的方面 发展. 然而, 对于目前常用的脉冲管制冷机而言, 随 着制冷机制冷量的增加, 其体积逐渐变大, 整体变得 更加笨重. 空间应用对低温制冷机的体积与重量有 着较为严苛的限制, 这种笨重的制冷机已经不能满 足空间应用的需求. 因此, 空间应用对于轻量化的大 冷量脉冲管制冷机的需求变得更加迫切.

美国国家标准局(NIST) Radebaugh 等人 ${ }^{[1]}$ 曾提
出采用更高的工作频率，可以在保证脉冲管制冷机 高效率的前提下，缩小制冷机的体积重量. 之后，国 内外逐渐兴起了对空间百赫兹脉冲管制冷机的研究. 空间百赫兹脉冲管制冷机的主要研究成果集中在小 冷量领域，2007年NGST(Northrop Grumman Space Technology)报道了一台 $100 \mathrm{~Hz}$ 微型化脉冲管制冷机, 扫气体积 $0.65 \mathrm{~cm}^{3}$, 整机重 $782 \mathrm{~g}$, 制冷性能为 1.1 W@77 $\mathrm{K}^{[2]}$. 2009年, NGST的Petach等人 ${ }^{[3]}$ 研制了一 台工作频率为 $100 \mathrm{~Hz}$ 的脉冲管制冷机, 当输人功率 为 $50 \mathrm{~W}$ 时, 在 $77 \mathrm{~K}$ 下具有 $1.3 \mathrm{~W}$ 制冷量. 2012年中国 科学院上海技术物理研究所研制了微型同轴脉冲管 制冷机, 整机重量 $2.2 \mathrm{~kg}$, 运行频率 $75 \mathrm{~Hz}$, 当输人功 率为 $80 \mathrm{~W}$ 时, 在 $80 \mathrm{~K}$ 具有 $2.5 \mathrm{~W}^{\text {制冷量 }}{ }^{[4,5]}$. 2017年中 国科学院理化技术研究所空间功热实验室, 研制了 质量为 $1.6 \mathrm{~kg}$ 微型化脉冲管制冷机, $45 \mathrm{~W}$ 电功率输人, 在 $80 \mathrm{~K}$ 可获得 $2.1 \mathrm{~W}$ 制冷量 ${ }^{[6]}$. 另外在非空间脉冲管

引用格式: 王乃亮, 赵密广, 陈厚否, 等. $72 \mathrm{~Hz}$ 大冷量空间脉冲管制冷机. 科学通报, 2018, 63: 3968-3974 Wang N L, Zhao M G, Chen H L, et al. Study of a $72 \mathrm{~Hz}$ high-capacity pulse tube cryocooler for space applications (in Chinese). Chin Sci Bull, 2018, 63: 3968-3974, doi: 10.1360/N972018-00107 
制冷机领域, 国内也成功研制了数台百赫兹大冷量 脉冲管制冷机. 2009年, 浙江大学吴英哲等人 ${ }^{[7]}$ 研制 的高频单级直线型脉冲管制冷机, 运行频率为 120 $\mathrm{Hz}, 500 \mathrm{~W}$ 电功输人, 在78.6 K 获得 $8 \mathrm{~W}$ 制冷量. 但是 该整机相对卡诺效率仅为 $4.4 \%$, 整机质量较重, 约 为 $11 \mathrm{~kg}$. 2012年, 中国科学院理化技术研究所热声组 设计了 $100 \mathrm{~Hz}$ 直线型脉冲管制冷机, 其在 $183 \mathrm{~W}$ 输人 电功下, $80 \mathrm{~K}$ 取得 $12.4 \mathrm{~W}$ 的制冷量, 整机相对卡诺效 率为 $18.4 \%$, 整机质量为 $8.9 \mathrm{~kg}$. 虽然整机效率较高, 但是该制冷机采用单缸压缩机驱动, 振动较大, 难以 应用到空间领域 ${ }^{[8]}$. 2017 年昆明物理研究所采用 redlich动磁式直线电机, 研制了一台 $10 \mathrm{~W} @ 80 \mathrm{~K}$ 同 轴型脉冲管制冷机, 其运行频率为 $62 \mathrm{~Hz}$, 输人电功 率为 $210.3 \mathrm{~W}$, 比卡诺效率可达 $12.66 \%{ }^{[9]}$.

总体来看, 在空间应用脉冲管制冷机领域, 主要 的研究成果集中在 $5 \mathrm{~W}$ 以下的小冷量方面, 而 $10 \mathrm{~W}$ 级以上轻量化整机鲜有报道. 虽然国内也开展了大 冷量的轻量化制冷机的研究, 但大多不是面向空间 应用的，不符合空间应用标准. 因此为了满足空间应 用对 $10 \mathrm{~W}$ 级以上的轻量化制冷机的需求, 亟需开展 空间大冷量脉冲管制冷机的轻量化研究工作. 本实 验室开展空间脉冲管制冷机研究数十年, 已成功在 航天卫星上搭载了数台脉冲管制冷机. 本文将沿用 成熟的空间制冷机研制技术，基于实验室自主研发 的大冷量脉冲管制冷机, 采用提高频率的方法, 开展 了空间大冷量脉冲管制冷机轻量化的研究. 为了提 高制冷机的运行频率, 本文首先分析了脉冲管制冷 机的蓄冷器长度、蓄冷器填料、充气压力等对频率的 影响规律, 随后对高频大冷量冷指进行了设计, 并通 过实验对脉冲管制冷机进行了相关的优化工作.

\section{1 冷指设计}

脉冲管制冷机主要由压缩机、冷指及调相机三部 分构成. 其中压缩机是一种压力波发生器, 压缩机的 输出 $P V$ 功可由下式得到:

$$
W_{P V}=\frac{1}{2} P \dot{V} \cos \theta=\pi f P_{m} V \cos \theta,
$$

其中 $f$ 为运行频率, $P_{m}$ 为工质的压力波幅值, $\dot{V}$ 为工 质的体积流率幅值, $V$ 为压缩机扫气体积, $\theta$ 为压力波 与体积流率的相位差. 根据式(1)可以知道, 当 $P_{m}$ 与 $\theta$ 变化不大时, 压缩机的输出PV功仅与其运行频率和 扫气体积有关, 如果提高了运行频率, 那么就可以在
压缩机PV功不变的前提下，降低压缩机的扫气体积. 一般而言，压缩机的体积、重量与其扫气体积成正相 关 ${ }^{[10]}$ ，因而通过提高运行频率，降低压缩机的扫气 体积, 就可以达到减轻压缩机质量的目的. 高频的压 缩机必须匹配高频的脉冲管冷指，否则整机性能就 会恶化. 冷指的高频化主要难点在于以下两点：其 一, 换热时间缩短, 单位体积换热量增加, 增加了设 计蓄冷器的难度; 其二, 蓄冷器内质量流与压力波之 间的相位关系恶化，增加了调相的难度. 因此，下文 将通过理论分析与实验研究相结合的方式, 进行超 高频冷指设计与优化工作.

\section{1 蓄冷器长度设计}

冷指是脉冲管制冷机的主要制冷部件，而蓄冷 器又是冷指的核心部件, 因此冷指的设计重点在于 蓄冷器的设计. 图1为脉冲管制冷机蓄冷器的内部相 位分布图 ${ }^{[1]}$. 根据该图可知, 蓄冷器热端质量流量 与冷端质量流量存在如下关系:

$$
\dot{m}_{h}=\dot{m}_{c}+\frac{\dot{P} V_{r g}}{R T_{r}}=\dot{m}_{c}+\frac{i 2 \pi f P V_{r g}}{R T_{r}},
$$

其中 $\dot{m}_{h}$ 和 $\dot{m}_{c}$ 分别为热端与冷端的质量流量, $\dot{P}$ 为压 力变化率, $V_{r g}$ 为蓄冷器体积, $T_{r}$ 为蓄冷器平均温度.

一般认为在蓄冷器人口处, 质量流量领先压力 波 $30^{\circ}$ 的相位角时, 蓄冷器整机性能较好 ${ }^{[12]}$. 根据公 式(2)可知, 当其他参数不变时, 如果单独提高制冷 机的运行频率，公式(2)右边第二项增加，这将会使 得热端质量流量 $\dot{m}_{h}$ 和冷端质量流量 $\dot{m}_{c}$ 之间的相位
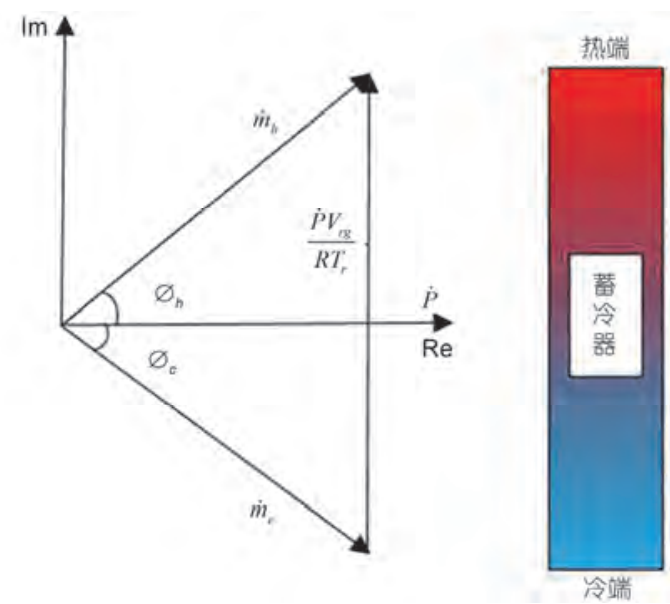

图 1 (网络版彩色)蓄冷器中质量流与压力波相位关系图

Figure 1 (Color online) Phasor diagram representing conservation of mass in the regenerator 
差变大, 从而增大了蓄冷器中的平均质量流量的幅 值. 质量流量的幅值大小与蓄冷器内工质的压降损 失成正比, 因此, 质量流量幅值的增大将会增加蓄冷 器内工质的压降损失. 另外质量流与压力波的相位 角也会因此相应增大, 相位角大于 $30^{\circ}$ 的最优相位角, 这也会一定程度上增大蓄冷器的换热损失.

为了消除由频率提升而带来的不良影响, 可以 通过减小蓄冷器的体积, 使得公式(2)右边第二项不 变. 在实际应用中, 一般通过减小蓄冷器的长度来达 到减小蓄冷器体积的目的. 因此, 为了提升脉冲管制 冷机冷指的运行频率, 需要缩短蓄冷器的长度.

\section{2 充气压力设计}

初始充气压力是脉冲管制冷机制冷性能的重要 影响因素之一, 其不仅影响制冷机冷指的泵热能力, 而且对压缩机的输人功率也有影响. 对式(1)进一步 推导可得压缩机 $W_{P V}$ 关于初始充气压力 $P_{0}$ 的关系式:

$$
W_{P V}=\pi f\left(\frac{P_{r}-1}{P_{r}+1}\right) P_{0} V \cos \theta,
$$

其中 $P_{r}$ 为压比, $P_{0}$ 为初始充气压力. 从公式中可以看 出, 当减小压缩机的扫气体积 $V$ 时, 为了保证总输出 功率 $W_{P V}$ 不变, 那么除了提高运行频率外, 也可以适 当提高初始充气压力.

另外对式(2)进一步推导可得公式(4). 为了抵消频 率提升而带来的损失, 需要保证公式(4)的值不变 ${ }^{[12]}$.

$$
\frac{\dot{P} V_{r g}}{\dot{m}_{1} R T_{r}}=\mathrm{K} \frac{f}{P_{0}\left(\frac{P_{r}-1}{P_{r}+1}\right)^{2}}=\text { constant, }
$$

其中 $\mathrm{K}$ 是综合系数. 从公式中可以看出, 当压比不变, 运行频率升高时, 为了保持该项数值不变, 那么就需 要适当地提升充气压力. 即脉冲管制冷机运行频率 提升时, 适当地提高充气压力能够提升整机的制冷 性能.

\section{3 蓄冷器填料设计}

相关研究表明, 为了保证工质与填料的充分换 热, 必须保证工质的热渗透深度要大于或相当于回 热器填料的水力直径 ${ }^{[13]}$. 氦气热渗透公式为

$$
\lambda=\sqrt{\frac{k}{f \rho \pi c_{p}}},
$$

式中 $\rho$ 为工质密度, $k$ 为导热系数, $c_{p}$ 为定压比热容. 从
式(5)可知, 氦气的热渗透深度随着频率的增加而减 小, 当工质的热渗透深度小于回热器填料的水力直 径时, 工质与填料的换热损失增加, 制冷机的效率降 低. 因此, 提高冷指的运行频率的同时, 需要选择水 力直径更小的填料.

综合以上分析可知, 为了提高脉冲管制冷机冷 指的运行频率, 在常用 $40 \mathrm{~Hz}$ 左右冷指基础上, 我们 需要缩短蓄冷器的体积、提高初始充气压力以及选用 水力直径更小的填料.

\section{2 实验装置介绍}

脉冲管制冷机实验装置如图2所示. 压缩机采用 本实验室自主研发的大功率的直线动圈式压缩机. 压缩机与制冷机冷指部分通过圆管相连接. 冷指热端 由水冷机提供的 $10^{\circ} \mathrm{C}$ 循环水冷却. 冷指放置在 $10^{-3} \mathrm{~Pa}$ 的真空罩中, 以减小辐射漏热. 冷头温度由铂电阻温 度计测量. 制冷量通过测量冷头 $80 \mathrm{~K}$ 时的加热片的 功率来获得. 调相部分将采用惯性管加气库的结构.

依据理论分析结果及实验室自研的13 W@80 K 大冷量脉冲管制冷机, 开展了超高频大冷量脉冲管 制冷机冷指的设计工作. 设计制冷机主要尺寸与运 行参数如表 1 所示; 蓄冷器外径尺寸与 $13 \mathrm{~W} @ 80 \mathrm{~K}$ 大 冷量脉冲管制冷机一致, 均为 $28 \mathrm{~mm}$, 且匹配相同的 压缩机. 蓄冷器长度缩短至了 $45 \mathrm{~mm}$ 及 $35 \mathrm{~mm}$.

\section{3 实验结果与分析}

\section{1 优化蓄冷器长度}

上文的理论分析指出, 为了提高冷指的最佳运 行频率, 需要缩短蓄冷器的长度. 本文在自主研发的 $13 \mathrm{~W} @ 80 \mathrm{~K}$ 大冷量脉冲管制冷机基础上, 加工设计 了相同外径, 长度更短的蓄冷器- $45 \mathrm{~mm}$ 蓄冷器与

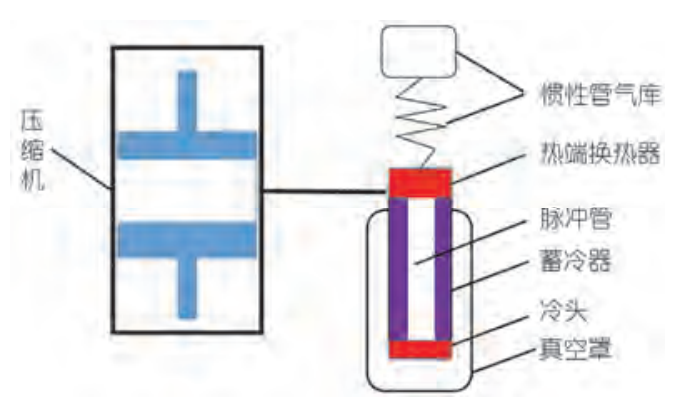

图 2 (网络版彩色)脉冲管制冷机实验装置示意图

Figure 2 (Color online) Schematic of the experimental apparatus 
表 1 制冷机主要尺寸与运行参数

Table 1 The main parameters of PTC

\begin{tabular}{lccl}
\hline \multicolumn{1}{c}{ 部件 } & 数值 & 部件 & \multicolumn{1}{c}{ 数值 } \\
\hline 压缩机扫气体积 & $10 \mathrm{~cm}^{3}$ & 调相机构 & 惯性管+气库 \\
蓄冷器直径 & $28 \mathrm{~mm}$ & 充气压力 & $4 \mathrm{MPa}$ \\
蓄冷器长度 & $35 \sim 45 \mathrm{~mm}$ & 连管 & 内径 $3 \mathrm{~mm}$, 长 $10 \mathrm{~cm}$ \\
\hline
\end{tabular}

$35 \mathrm{~mm}$ 蓄冷器. 将新加工的短蓄冷器匹配同一冷指热 端, 蓄冷器中均填充500目不锈钢丝网, 匹配同一压 缩机, 得到的实验结果如图3所示. 可以看到随着蓄 冷器长度由 $60 \mathrm{~mm}$ 缩短到 $35 \mathrm{~mm}$, 制冷机最佳运行频 率由 $38 \mathrm{~Hz}$ 上升至 $72 \mathrm{~Hz}$. 从该实验结果可以看出, 当 蓄冷器长度缩短时, 冷指需匹配更高的运行频率, 以 保证蓄冷器内部相位角处于合理范围. 因此, 缩短蓄 冷器的长度, 成为了提高制冷机的最佳运行频率一 种有效手段. 但是从该图中可以看出, 随着蓄冷器长 度逐渐缩短, 制冷机的制冷能力逐渐降低了. 这说明 研制超高频的冷指, 并不是简单地缩短蓄冷器的长 度就够了. 冷指频率的提升, 对制冷机其他参数也提 出更高的要求, 需要进一步优化其他参数以提高制 冷机的效率.

\section{2 优化充气压力}

图4展示了 3 种频率下制冷机在 2.5 4.0 MPa充气 压力范围内制冷性能. 从该图中可以看出, 不同频率 的制冷机所对应的最佳充气压力是不同的. $38 \mathrm{~Hz}$ 的 制冷机最佳充气压力在 $3.0 \mathrm{MPa}$ 左右, $52 \mathrm{~Hz}$ 的制冷机 最佳充气压力约为 $3.5 \mathrm{MPa} .72 \mathrm{~Hz}$ 的制冷机最佳充气

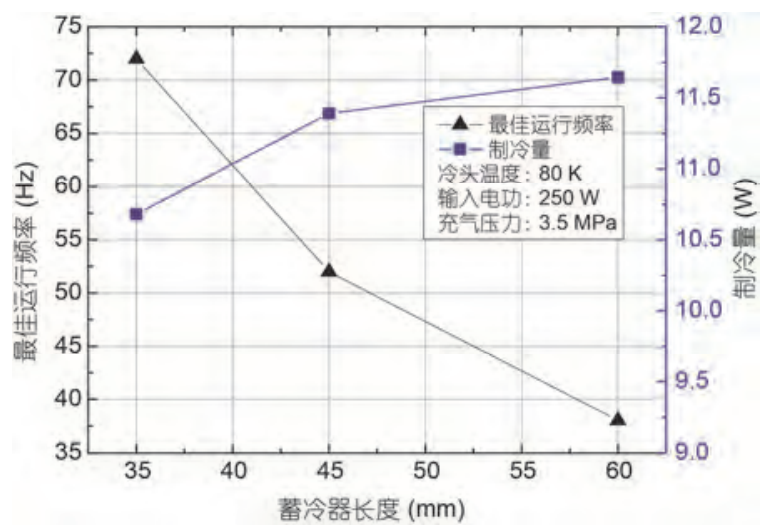

图 3 (网络版彩色)不同长度冷指的制冷量与最佳运行频率图

Figure 3 (Color online)The cooling performance and optimal frequencies of different pulse tube cryocoolers

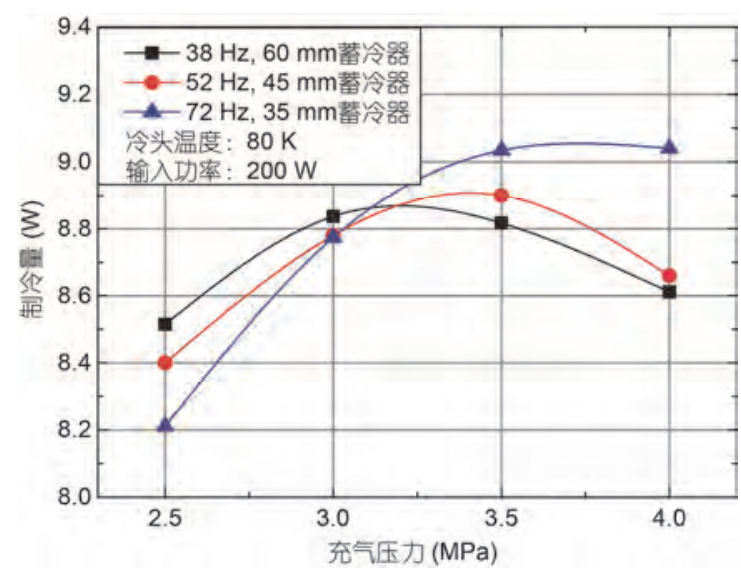

图 4 (网络版彩色)充气压力对不同频率制冷机的性能影响

Figure 4 (Color online) The cooling capacity at $80 \mathrm{~K}$ vs. charge pressure

压力在3.5 4 MPa之间. 该实验结果证明，当制冷机 最佳运行频率较高时, 其对应的最佳充气压力也是 较高的. 这主要因为一方面, 较高的充气压力代表着 较大的工质密度. 以保证在较短的蓄冷器中, 也具有 充足的做功工质, 以获得足够的制冷量. 另一方面, 适当的提高充气压力, 也能够一定程度上优化蓄冷 器内的相位关系, 以抵消频率提升而带来的负面影 响. 然而, 充气压力并不是越高越好, 充气压力越 高, 质量流量越大, 进而蓄冷器内压力损失也就越 大. 对于不同的制冷机, 均存在一个最佳的充气压 力, 使得整机性能达到最佳.

\section{3 优化蓄冷器填料}

不锈钢丝网是目前液氮温区脉冲管制冷机常用 的蓄冷器填料, 一般不锈钢丝网的目数越高, 则其水 力直径越小. 通常, 脉冲管制冷机运行频率低于 $50 \mathrm{~Hz}$ 时, 其最佳的不锈钢丝网目数为300 500目左 右 ${ }^{[14 ~ 15]}$. 而当制冷机运行频率高于 $50 \mathrm{~Hz}$ 时, 情况将 有所不同. 本文选取了 $35 \mathrm{~mm}$ 蓄冷器, 分别填充400 635目不锈钢丝网, 通过实验研究了不同目数不锈钢 丝网对制冷机整机性能的影响规律. 图 5 为此 3 种制 冷机的制冷曲线图.

从图中可以发现, 随着蓄冷器填充丝网目数的 提高, 制冷机的制冷量逐渐提升, 该 $72 \mathrm{~Hz}$ 冷指所需 的最佳丝网为 635 目不锈钢丝网. 而我们研制的 $38 \mathrm{~Hz}$ 冷指所需的最佳不锈钢丝网为 400 目与 500 目. 出现这个差别的主要原因在于, 工质氦气的热渗透 深度随着频率的提升而降低, 制冷机运行频率越高 


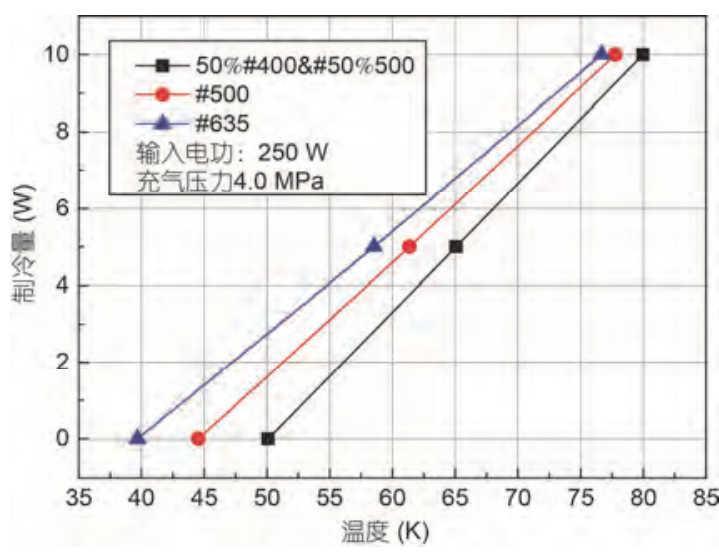

图 5 (网络版彩色)蓄冷器填充不同丝网的制冷机的制冷性能对比 Figure 5 (Color online) The cooling capacity at $80 \mathrm{~K}$ vs. cold temperature

时, 就需要水力直径更细的丝网来加强换热. 换言 之, 当脉冲管制冷机的运行频率较高时, 较低目数的 不锈钢丝网已经不能满足其换热需求, 需要选用较 高目数的丝网以达到更好的换热效果.

另外, 从图中可以看出, 随着不锈钢丝网目数的 不断提高, 制冷机的最低无负荷温度逐渐降低, 制冷 机在较低温区的制冷能力愈加凸显. 这是因为一方 面高目数丝网能够填充的片数增多, 增大了轴向接 触热阻, 减小了轴向漏热损失. 另一方面, 随着温度 降低, 氦气工质的热渗透深度下降. $60 \mathrm{~K}$ 以下的低温 区需求的填料水力直径更小, 因而高目数丝网将具 有更好的换热效果.

\section{4 脉冲管制冷性能}

图6展示了 $72 \mathrm{~Hz}$ 脉冲管制冷机在不同输人电功 率下的制冷能力, 并将其200 250 W 输人功率下的制 冷能力与 $38 \mathrm{~Hz}$ 制冷机进行了对比. 从图中可以看出, 在相同输人功率时, $72 \mathrm{~Hz}$ 的脉冲管制冷机最低无负 荷温度较高, 但是单位温升的制冷量较大 (即图中的 曲线斜率较大). 这主要是因为 $72 \mathrm{~Hz}$ 冷指长度较短, 轴向漏热更大, 难以获得较低的无负荷温度; 然而, 蓄冷器长度缩短, 减小了蓄冷器内压降损失, 因而单 位温升的制冷量较大. 在 $60 \mathrm{~K}$ 温区左右, $72 \mathrm{~Hz}$ 制冷 机制冷斜率与 $38 \mathrm{~Hz}$ 制冷机制冷斜率相交, 即表明在 $60 \mathrm{~K}$ 温区以下时, $38 \mathrm{~Hz}$ 制冷机制冷能力较高; 在 $60 \mathrm{~K}$ 温区之上时, $72 \mathrm{~Hz}$ 制冷机制冷能力较高.

该72 $\mathrm{Hz}$ 大冷量脉冲管制冷机的典型性能是在 $250 \mathrm{~W}$ 输人电功下, 在 $80 \mathrm{~K}$ 可以获得最大 $12 \mathrm{~W}$ 的制

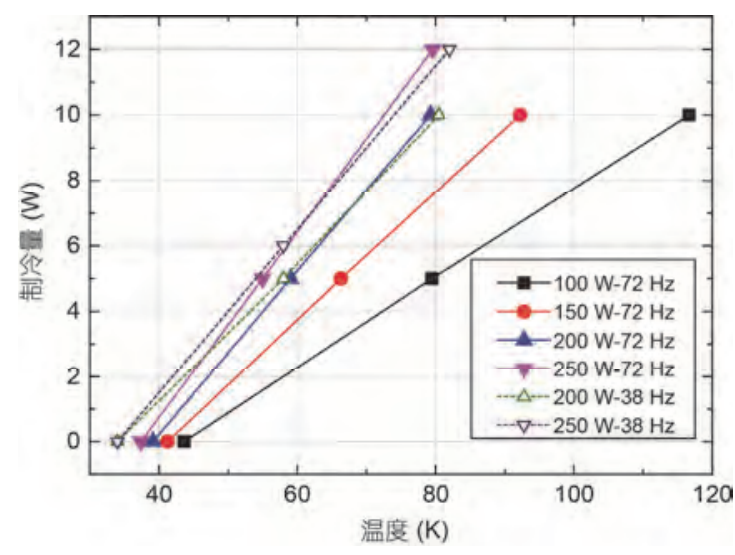

图 6 (网络版彩色) $72 \mathrm{~Hz}$ 与 $38 \mathrm{~Hz}$ 大冷量脉冲管制冷机制冷性能曲 线图

Figure 6 (Color online) Cooling performance map of the $72 \mathrm{~Hz}$ and 38 Hz PTC

冷量, 相对电功卡诺效率可达 $13.2 \%$. 在 $100 \mathrm{~W}$ 输人 电功下, 可以获得约 $5 \mathrm{~W} @ 80 \mathrm{~K}$ 的制冷量, 相对电功 卡诺效率最高可达 $13.75 \%$. 说明该 $72 \mathrm{~Hz}$ 同轴型脉冲 管制冷机制冷效率较高, 已达到国内先进水平.

本文通过实验研究获得了一台高效 $72 \mathrm{~Hz}$ 大冷量 脉冲管制冷机. 将该制冷机与实验室自主研制的 $38 \mathrm{~Hz}$ 大冷量脉冲管制冷机进行对比, 如表2所示. 从 表中可以看出, 在相同直径的前提下, 将蓄冷器的长 度由 $60 \mathrm{~mm}$ 缩短至 $35 \mathrm{~mm}$, 可以使制冷机的最佳运行 频率由 $38 \mathrm{~Hz}$ 提升至 $72 \mathrm{~Hz}$. 得益于频率的提升, 在相 同 $250 \mathrm{~W}$ 电功时, $72 \mathrm{~Hz}$ 高频制冷机所需的扫气量为 $4.4 \mathrm{~cm}^{3}$, 仅为 $38 \mathrm{~Hz}$ 低频制冷机所需扫气量 $8.6 \mathrm{~cm}^{3}$ 的 一半左右. 但是简单地缩短蓄冷器的长度会使得制 冷机整机效率变差, 因此本文进一步采取了提高了 蓄冷器填料的目数及初始充气压力的方法, 以降低 冷指高频化而带来的换热等损失. 最终, 通过理论分

表 $272 \mathrm{~Hz}$ 高频冷指与 $38 \mathrm{~Hz}$ 低频冷指对比

Table 2 The comparison of $72 \mathrm{~Hz}$ cryocooler and $38 \mathrm{~Hz}$ cryocooler

\begin{tabular}{lll}
\hline \multicolumn{1}{c}{ 性能 } & $38 \mathrm{~Hz}$ 制冷机 & $72 \mathrm{~Hz}$ 制冷机 \\
\hline 蓄冷器直径 $(\mathrm{mm})$ & 28 & 28 \\
蓄冷器长度 $(\mathrm{mm})$ & 60 & 35 \\
最佳运行频率 $(\mathrm{Hz})$ & 38 & 72 \\
输人电功 $(\mathrm{W})$ & 250 & 250 \\
压缩机扫气体积 $(250 \mathrm{~W})\left(\mathrm{cm}^{3}\right)$ & 8.6 & 4.4 \\
蓄冷器填料 & $\# 400 \& \# 500$ & $\# 635$ \\
初始充气压力 $(\mathrm{MPa})$ & 3.5 & 4.0 \\
$80 \mathrm{~K}$ 制冷量 $(\mathrm{W})$ & 11.6 & 12 \\
\hline
\end{tabular}




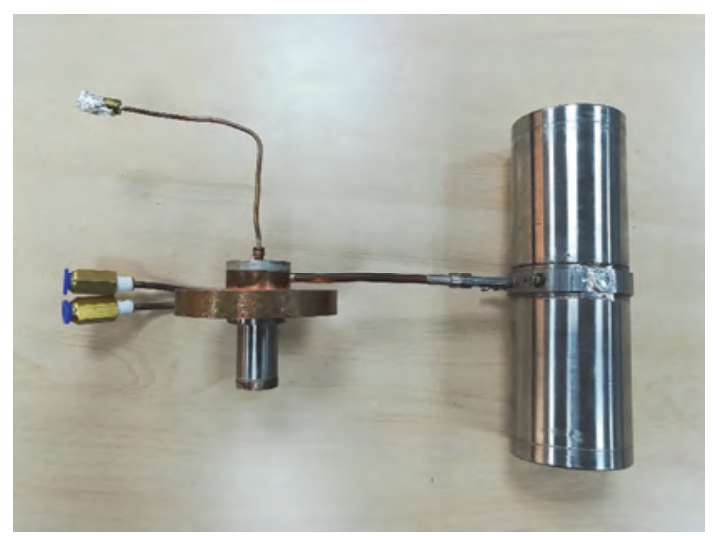

图 7 (网络版彩色) $72 \mathrm{~Hz}$ 制冷机冷指实物图

Figure 7 (Color online)The photograph of $72 \mathrm{~Hz}$ cryocooler without phase shifter

析及实验研究, 成功研制了高效率的高频 $72 \mathrm{~Hz}$ 大冷 量脉冲管制冷机, 达到了与传统 $38 \mathrm{~Hz}$ 制冷机相同的 制冷水平, 甚至整机效率与制冷量要略高于传统 38 $\mathrm{Hz}$ 的制冷机的冷量. 图7展示了该 $72 \mathrm{~Hz}$ 制冷机的实 物图.

\section{4 结论与分析}

本文通过理论研究, 详细分析了提升脉冲管制 冷机频率的有效方法. 结合自主研发的 $38 \mathrm{~Hz}$ 大冷量 脉冲管制冷机，设计了超高频的大冷量脉冲管制冷 机冷指. 并通过实验研究了蓄冷器长度、初始充气压 力、与蓄冷器填料尺寸等对制冷机运行频率和制冷效 率的影响规律, 验证了理论分析的正确性. 最终成功 研制了一台可应用于空间的 $72 \mathrm{~Hz}$ 大冷量同轴型脉冲 管制冷机，该制冷机在 $250 \mathrm{~W}$ 输人电功下，最高拥有 $12 \mathrm{~W} @ 80 \mathrm{~K}$ 的冷量, 相对电功卡诺效率可达 $13.2 \%$, 在同类型的制冷机中，整机效率处于领先水平. 同 时，该制冷机沿用成熟的空间制冷机研制技术，结构 紧凑、稳定性高、易于工程化，其工程样机可以达到 与该实验样机相同乃至相近的效率. 该高效 $72 \mathrm{~Hz}$ 冷 指的成功研制, 解决了整机轻量化的首要难题, 为空 间用大冷量脉冲管制冷机的轻量化研究奠定了坚实 的基础. 下一阶段, 我们将着手进行线性压缩机小型 化的研究, 以进一步降低整机的重量.

\section{参考文献}

1 Radebaugh R, O'Gallagher A. Regenerator operation at very high frequencies for microcryocoolers. In: Weisend J G, ed. AIP Conference Proceedings. American Institute of Physics Press, 2006, 823: 1919-1928

2 Petach M, Waterman M, Tward E, et al. Pulse tube microcooler for space applications. Cryocoolers, 2007, 14: 89-93

3 Petach M, Waterman M, Pruitt G, et al. High frequency coaxial pulse tube microcooler. Cryocoolers, 2009, 15: 97-103

4 Dang H Z. Development of High Frequency Pulse Tube Cryocoolers for Space Applications. In: Weisend J G, ed. AIP Conference Proceedings. New York: American Institute of Physics Press, 2012, 1434: 1457-1464

5 Cao Y G, Chen X, Wu Y N. Review of key technologies of Stirling-type pulse tube cryocoolers for space application (in Chinese). Infrared, 2013, 34: 1-9 [曹永刚, 陈曦, 吴亦农. 空间用斯特林型脉管制冷机的应用现状研究. 红外, 2013, 34: 1-9]

6 Xin E C, Chen H L, Tang Q J, et al. Investigation on the $1.6 \mathrm{~kg}$ miniature coaxial pulse tube cryocooler (in Chinese). Vac Cryogenics, 2017, 23: 217-222 [邢恩春, 陈厚否, 唐清君, 等. $1.6 \mathrm{~kg}$ 小型同轴脉冲管制冷机实验研究. 真空与低温, 2017, 23: 217-222]

7 Gan Z H, Wu Y Z, Yuan Y, et al. Theoretical and experimental study on a $120 \mathrm{~Hz}$ single stage pulse tube cryocooler (in Chinese). J Zhejiang Univ (Eng Sci), 2011, 45: 2014-2019 [甘智华, 吴英哲, 袁园, 等. $120 \mathrm{~Hz}$ 单级脉管制冷机理论与实验. 浙江大学学报(工 学版), 2011, 45: 2014-2019]

8 Wang X T. Study on the operating principle of high frequency pulse tube cooler (in Chinese). Doctor Dissertation. Beijing: Graduate School of Chinese Academy of Science, 2012 [王晓涛. 超高频脉冲管制冷机的特性研究. 博士学位论文. 北京: 中国科学院研究生 院, 2012]

9 Xiong C, Xi Z L, Xu H, et al. Experimental performance of a $10 \mathrm{~W} / 80 \mathrm{~K}$ high frequency coaxial pulse tube cryocooler (in Chinese). Cryogenics, 2017, (3): 34-37 [熊超, 习中立, 许红, 等. 10 W/80 K 高频同轴脉冲管制冷机的实验性能. 低温工程, 2017, (3): 34-37]

10 Gan Z H, Wu Y Z, Yuan Y, et al. Therotical and experimental study on a $120 \mathrm{~Hz}$ single stage pulse tube cryocooler. J Zhejiang Univ, 2011, 45: 2014-2019

11 Chen G B, Tang K. The Principle of Miniature Refrigerator (in Chinese). Beijing: Science Press, 2009. 256-257 [陈国邦, 汤珂. 小型低 温制冷机原理. 北京: 科学出版社, 2010. 256-257]

12 Vanapalli S, Lewis M, Gan Z, et al. $120 \mathrm{~Hz}$ pulse tube cryocooler for fast cooldown to $50 \mathrm{~K}$. Appl Phys Lett, 2007, 90 : 163

13 Radebaugh R. Microscale Heat Transfer at Low Temperatures. Nato Sci, 2005, 193: 93-124

14 Dang H Z, Wang L B, Yang K X. 10 W/90 K single-stage pulse tube cryocoolers. Cryogenics, 2012, 52: 221-225

15 Wang K, Dubey S, Choo F H, et al. Modelling of pulse tube refrigerators with inertance tube and mass-spring feedback mechanism. Appl Energ, 2016, 171: 172-183 
Summary for “72 Hz 大冷量空间脉冲管制冷机”

\title{
Study of a $72 \mathrm{~Hz}$ high-capacity pulse tube cryocooler for space applications
}

\author{
Nailiang Wang ${ }^{1,2}$, Miguang Zhao ${ }^{1 *}$, Houlei Chen ${ }^{1} \&$ Jingtao Liang ${ }^{1}$ \\ ${ }^{1}$ Key Laboratory of Space Energy Conversion Technologies, Technical Institute of Physics and Chemistry, Chinese Academy of Sciences, Beijing \\ 100190, China; \\ ${ }^{2}$ University of Chinese Academy of Sciences, Beijing 100049, China \\ * Corresponding author, E-mail: mgzhao@mail.ipc.ac.cn
}

Most infrared detectors work at low temperature, which enhances their detection sensitivity and visual field. Nowadays, the cryocoolers commonly used in space detectors are Stirling and pulse tube cryocoolers (PTCs). Compared with the Stirling cryocoolers, PTCs have no moving parts in the cold finger, resulting in low vibration and long lifetimes, and after decades of development, some PTCs already have comparable efficiencies to Stirling models. Thus, PTCs have been considered as ideal substitutes for Stirling cryocoolers in the future. In recent years, with the rapid progress of aerospace applications, the structure and the function of infrared detectors have become more complicated, requiring a higher cooling capacity. However, increasing cooling power always increases of the PTC's weight, whereas many special aerospace applications have strict size and weight restrictions. As a result, miniaturization of high-capacity PTCs is required urgently in space applications.

According to the Radebaugh's research, increasing the operation frequency of PTCs can be an efficient way to minimize their size and mass because a high operating frequency can increase the energy density. Thus, many researchers and institutions at home and abroad have focused on the study of miniaturized PTCs, but most of the work is carried out on the PTCs used in space with cooling capacities under $5 \mathrm{~W}$. Although some studies have been conducted on high-capacity miniature PTCs in China, none are designed for space applications. Thus, there is an urgent demand for miniaturized PTCs with cooling power above $10 \mathrm{~W}$ at $80 \mathrm{~K}$.

To minimize the sizes and weights of PTCs, the influences of the length of the regenerators, the charging pressure, and the regenerator matrix upon the operating frequency are presented. The results show that decreasing the volume of the regenerator, increasing the charge pressure, and decreasing the hydraulic diameter of the matrix are beneficial for promoting PTC efficiency with high operating frequency. On the basis of this optimization, 35-mm and 45-mm-length regenerators are designed and manufactured. Some systematic experiments are carried out using the newly designed PTCs. The experimental results also demonstrate that the length of the regenerator, charge pressure, and hydraulic diameter of the matrix significantly impact the efficiency of PTCs with high operating frequencies. Finally, a $72-\mathrm{Hz}$ high-capacity coaxial-pulse-tube cryocooler is obtained with a cooling capacity of $12 \mathrm{~W}$ at $80 \mathrm{~K}$ and an input electrical power of $250 \mathrm{~W}$. It achieves around $13.2 \%$ of the Carnot efficiency at $80 \mathrm{~K}$, which is high compared with the same kind of PTCs. Benefiting from our mature techniques in space-PTC design, this PTC is easy to transform into an engineering model with little difference in efficiency. The success of the design of a 72-Hz PTC cold finger solves the critical problem of ministration and can provide some theoretical and experimental guidance for the design of miniaturized PTCs for space applications.

12 W@80 K, coaxial, pulse tube cryocooler, $72 \mathrm{~Hz}$

doi: 10.1360/N972018-00107 